\title{
Treatment of femoral neck fractures in elderly patients over 60 years of age - which is the ideal modality of primary joint replacement?
}

\author{
Christian Ossendorf*, Max J Scheyerer, Guido A Wanner, Hans-Peter Simmen, Clément ML Werner
}

\begin{abstract}
Background: Femoral neck fractures in the elderly are frequent, represent a great health care problem, and have a significant impact on health insurance costs. Reconstruction options using hip arthroplasty include unipolar or bipolar hemiarthroplasty (HA), and total hip arthroplasty (THA). The purpose of this review is to discuss the indications, limitations, and pitfalls of each of these techniques.

Methods: The Pubmed database was searched for all articles on femoral neck fracture and for the reconstruction options presented in this review using the search terms "femoral neck fracture", "unipolar hemiarthroplasty", "bipolar hemiarthroplasty", and "total hip arthroplasty". In addition, cross-referencing was used to cover articles eventually undetected by the respective search strategies. The resulting articles were then reviewed with regard to the different techniques, outcome and complications of the distinct reconstruction options.
\end{abstract}

Results: THA yields the best functional results in patients with displaced femoral neck fractures with complication rates comparable to HA. THA is beneficially implanted using an anterior approach exploiting the internervous plane between the tensor fasciae latae and the sartorius muscles allowing for immediate full weight-bearing. Based on our findings, bipolar hemiarthroplasty, similar to unipolar hemiarthroplasty, cannot restorate neither anatomical nor biomechanical features of the hip joint. Therefore, it can only be recommended as a second line of defenseprocedure for patients with low functional demands and limited live expectancy.

Conclusions: THA is the treatment of choice for femoral neck fractures in patients older than 60 years. HA should only be implanted in patients with limited life expectancy.

\section{Background}

Femoral neck fractures are frequent injuries in the patient population of every trauma center and have a high incidence in the general population. Paralleling trends of demographic forecasts, their incidence will continue to rise in the future [1,2]. Especially in the elderly, femoral neck fractures represent a significant health care problem and have enormous impact on health insurance costs. Therefore, the appropriate treatment of femoral neck fractures is mandatory. Today, surgery is the mainstay of care. While in younger patients (20-50 years), closed reduction and internal fixation (CRIF) is routinely performed, the treatment of older patients with intracapsular femoral

\footnotetext{
* Correspondence: Christian.Ossendorf@usz.ch

Department of Surgery, Division of Trauma Surgery, University of Zurich, Raemistrasse 100, 8091 Zurich, Switzerland
}

neck fractures largely depends on local conditions, patient profiles, personal preferences and training of the surgeon. This is merely based on personal believes determining the management of patients than evidence from the literature $[3,4]$. In the authors' country e.g. general surgeons provide care in musculoskeletal trauma, while this care is provided by orthopaedic trauma surgeons elsewhere. Often, the type of implant is dictated by the surgeons training. Worldwide, some surgeons treat older patients similar to younger ones by CRIF using cannulated screws or devices like the sliding hip screw. In contrast, reconstruction options include: hemiarthroplasty (HA) - unipolar and bipolar - and total hip arthroplasty (THA). Hence, the optimal treatment of this patient population is still under debate [5]. Therefore, surgeons cannot be sure, whether they offer the best care available to their patients. The present review focuses on the treatment of femoral neck 
fractures in patients of 60 years and older to discuss indications, techniques, limitations and problems of each of these techniques. It aims to distil from the literature the best available treatment for this important patient population.

\section{Methods}

We performed a review of all studies about femoral neck fractures treated with either hemiarthroplasty or THA published between Jan 01, 1975 and December 31, 2009. All publications were derived from NCBI-PubMed http:// www.pubmed.gov using the search-term "femoral neck fracture" combined with "unipolar hemiarthroplasty", "bipolar hemiarthroplasty", or "total hip arthroplasty", and "total hip replacement", respectively. Studies other than written in English, French, Spanish or German were disregarded. Those about non-traumatic etiologies, e.g. degenerative joint disease, revision arthroplasty, pathologic fractures or rheumatoid arthritis, articles covering hip resurfacing, and biomechanical studies, as well as case reports were excluded from the present study. Duplicates were eliminated from further analysis.

\section{Results}

\section{Hemiarthroplasty (Uni- and bipolar)}

Advantages of monopolar (Figure 1) and bipolar arthroplasty (Figure 2) compared to THA include short operation time and quick mobilization of the patient. Good or at least acceptable clinical, functional and radiological results have been reported in a wide array of studies [6-20]. However, whether unipolar or bipolar hemiarthroplasty (HA) provide better results is still under debate [20-24].

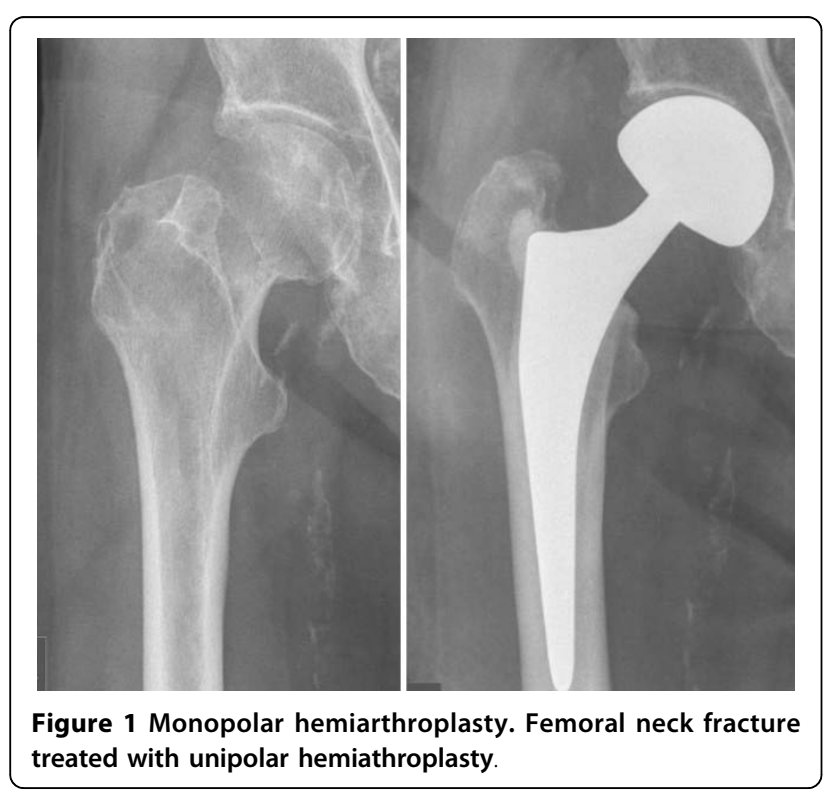

Single component devices are based on models pioneered by Moore and Thompson in the 1950's [21,22]. Since then, this type of prosthesis has gained popularity for the treatment of displaced femoral neck fractures because of its ease to implant in a short period of time. In addition, the Bateman prosthesis, designed by Bateman in the early 1970 s to reduce acetabular wear as frequently seen with the Moore and Thompson types, was an important innovation with better functional outcome assessed by the Harris hip score [23,24]. Monopolar HA cause significant acetabular wear and subsequent problems [25]. Reduction usually is somewhat more difficult in monopolar arthroplasty compared to bipolar ones and particularly to THA.

Bipolar hemiprostheses consists of a metal cup that serves as an outer head, a metal femoral component, and a polyethylene insert in between. Here, a multiplebearing principle is effected by creating a double layer of universal motion. The major movement occurs at the inner bearing, as the addition of weight shifts most of the motion to the inner bearing reducing the damaging effect of metal against the acetabular floor. That way, a low-friction layer at the metal head-plastic interface, with much less frictional torque than the one developed at the outer shell acetabular interface is provided [26]. Usually, these prosthetic devices are implanted using a lateral Hardinge, i.e. transgluteal or an anterolateral Watson-Jones, approach [27-29]. Both approaches provide good visualization of acetabulum and femur while somewhat decreasing the risk of luxation compared to a posterior approach. The disadvantages and dangers of implanting arthroplasty using a transgluteal approach have been extensively documented, including malorientation of the cup, destruction of the abductor mechanism by cutting the external rotators making immediate full weight-bearing is impossible [30-35].

Another disadvantage of bipolar hemiarthroplasty lies within the construction principle: after approximately one year, bipolar hemiarthroplasty act as unipolar hemiarthroplasty [36-38], as the outer metal-on-bone friction is supposed to be higher and movements transferred to the inner metal-on-polyethylene bearing in arthritic patients [38]. Consequently the bipolar cup tend to horizontalize and remain within this position (Figure 2), [38-43]. However, the exact clinical consequences of this unintended positioning remain unclear.

There is a considerable complication rate in unipolar and bipolar hemiarthroplasty [44], independent of whether a junior or senior surgeon performed the procedure [45]. Hemiarthroplasty comprise considerable need for reoperation often necessitating conversion to THA [46-48]. This may also be explained by neglecting - and not restoring - the femoral offset $[49,50]$. due to old-fashioned design which does account for anatomical 


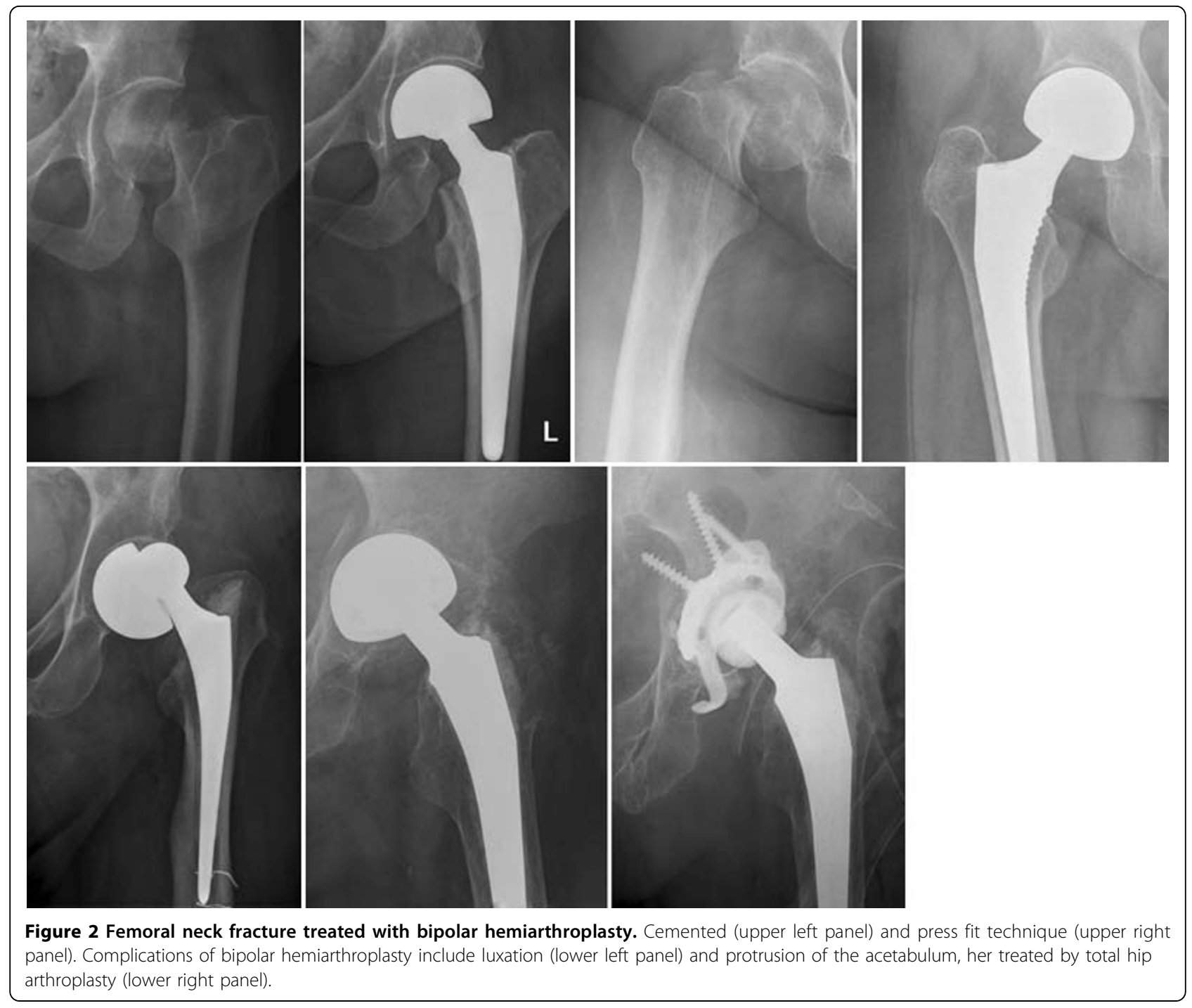

and biomechanical features of the hip joint and the femoral neck. Hence, restoring the individual offset is often impossible using unipolar and bipolar hemiarthroplasty. Consecutively, sufficient tissue tension balancing is impaired. Adequate treatment of double fond conditions of the acetabulum cannot be acceptably addressed using bipolar HA.

Further complications of bipolar hemiarthroplasty include intra-operative metaphyseal fractures reported in $10 \%$ of cases in a series of 273 patients with displaced femoral neck fractures, depending on extension of fracture dislocation [51]. The dislocation rate was reported to be $1.5 \%$ in a large series of 1934 hips [52], half of which redislocate after reduction. Other authors reported $4 \%$ dislocation rate $[53,54]$. Additional problems associated with bipolar hemiarthroplasty are migration of the bipolar head, as well as stem migration [55], failure of the polyethylene inlay [56], and component disassembly
[57-61]. Heterotopic ossification is more frequent in cemented than in uncemented bipolar hemiarthroplasty [62]. However, pain relief and function are better in patients with bipolar hemiarthroplasty -regardless of cemented or uncemented- compared to unipolar arthroplasty [63]. In order not to miss anterior narrowing of the joint line, axial views must be done as cross-table.

Both, unipolar and bipolar hemiarthroplasty increase biomechanical stresses on the acetabular bone and that way cause migration of the head with consecutive destruction of the acetabulum, as demonstrated in a finite element model [64]. Although some reports describe little acetabular erosion [65-67], several studies demonstrated significant acetabular wear in up to $67 \%$ of cases, resulting in an average time to failure of 38 months $[8,68,69]$. This wear was quantified with an average rate of $0.7 \mathrm{~mm}$ per year [68]. These prostheses are therefore only recommended in old patients with limited life 
expectancy. A recent review of the current evidence for internal fixation versus hemiarthroplasty versus primary total hip arthroplasty for displaced femoral neck fractures showed no difference in mortality, postoperative pain, function, or quality of life for either of the devices. For hemiarthroplasty, the data suggest minimal differences in outcome between the prosthesis types [70]. Summing up the findings from the literature, hemiarthroplasty are preferentially performed in older patients with limited life expectancy and low functional demands.

\section{Total Hip Arthroplasty}

In most western European countries and in the U.S., arthroplasty is the mainstay of surgical treatment of intracapsular femoral neck fractures in patients older than 60 to 65 years [71-73]. Here, total hip arthroplasty yields good clinical short to long-term results $[1,74]$ with significantly less pain and better outcomes represented by quality of life and functional scores [75] (SF36 and WOMAC) compared to hemiarthroplasty [76]. Along with the improvement of implants, THA has gained attention for the treatment of displaced femoral neck fracture and importance even in countries traditionally treating this group of patients with internal fixation or with unipolar devices (Figure 3).

In a 1993 series, the following prognostic factors were found: nursing home patient, chronic pulmonary disease, serum creatinine level greater than $1.7 \mathrm{mg} / 100 \mathrm{ml}$, pneumonia, previous myocardial infarction, duration of surgery, and gender. In contrast, the following factors had no significant influence on mortality: age, time delay from admission to surgery, mode of anesthesia, and cerebrovascular diseases [77]. In contrast, sex, age, waiting time before surgery, stroke, dislocation of the prosthesis and perioperative fracture were identified as key factors negatively influencing outcome at 3 months postoperatively [78].

Independent of the surgical procedure (internal fixation, HA, THA), no statistical effect of time to surgery on mortality could be shown in a series of 2916 patients [79]. In contrast, in a smaller study including 265 consecutive patients, delayed hospitalization of more than 6 hours after trauma was related to higher mortality [80]. However, early surgery within 24 hours was associated with reduced length of hospitalization, although mortality was higher in men at 4 and 12 months with administrative delay in surgery compared to patients with no delay $[81,82]$. To adequately restore physical activities after surgery, intensive rehabilitation schemes are of paramount importance [83].

Transfusion rates have been shown to be less using minimally invasive techniques [84]. Here, dislocation rates were lower than using other approaches [85-87]. Particularly the posterior approach makes THA prone to dislocation [88]. The anterior approach allows for immediate full weight-bearing, as only the pars reflecta of the rectus femoris muscle is partially detached for this approach and the external rotators of the hip are protected from preventable iatrogenic damage. In contrast, the lateral cutaneous femoral nerve may be at risk using this approach.

Studies comparing bipolar hemiarthroplasty and total hip arthroplasty (THA) showed that THA yields better function at the same complication rate approximately one year postoperatively [89]. Here, functional outcome was better in THA patients than in patients with HA $[73,90]$. Comparing internal fixation, unipolar Hemiarthroplasty, bipolar hemiarthroplasty and total hip arthroplasty, THA was the most cost effective treatment [91]. In the appropriate patient population, outcomes following total hip arthroplasty are favorable and appear to be superior to those of internal fixation. THA patients had less pain and better function compared to HA patients at the same rate of complications two years postoperatively [76], and bipolar hemiarthroplasty always showed inferior function, worse long-term results, and higher revision rates [46-48,92]. Therefore, conversion of HA to THA is necessary at times $[68,93]$. In comparison to internal fixation alone, arthroplasty appears superior and significantly reduces the number of surgical revisions. It decreases the rate of complications without increased mortality $[1,5]$. After 2 years of follow-up, the rate of secondary fracture dislocation and need for revision surgery was less in patients treated with THA compared to those treated with cannulated screws [37].

After failed internal fixation, conversion to THA can effectively restore function and relieve pain, too [94]. As the costs of revision arthroplasty are immense and the patients are even older at this point of time, physically fit patients may beneficially be treated with primary THA [95].

THA is not suitable for every patient including multimorbid patients, or patients with limited live expectancy [96]. Migration at two years is is predictive of the longterm evolution of an implant; cup migration of $1 \mathrm{~mm}$ or more at 2 years is predictive of late failure [97].

Disadvantages of THA include higher blood loss and costs compared to bipolar hemiarthroplasty which are approximately $\$ 12^{\prime} 290$ vs. to $\$ 8876$ for monopolar hemiarthroplasty [63]. Although the initial costs of THA are greater compared to unipolar or bipolar devices, overall costs are regarded as lower, because of increased long-term survival, better outcome and less frequent reoperations. Complications of femoral neck fracture comprise femoral implant failure including the stem, neck, and the modular head-neck junction, and loosening. Loosening is primarily associated with wear particles $[98,99] 0.1 \mathrm{~mm}$ wear per year is the threshold for a 


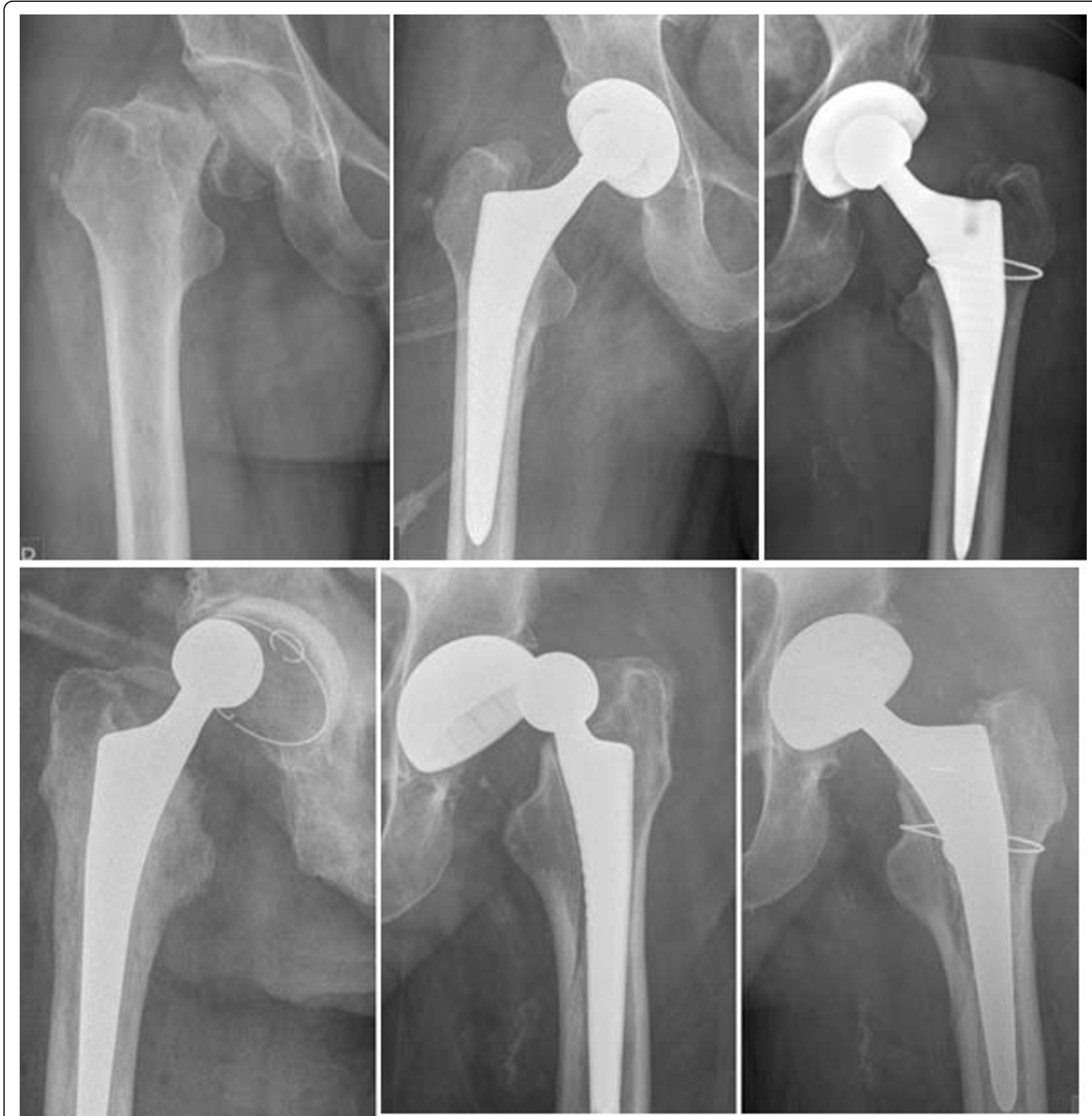

Figure 3 Femoral neck fracture treated with total hip arthroplasty (upper left panel). Potential complications and pitfalls include fracture of the trochanter (upper right panel), luxation (lower left panel), both (lower right panel).

normal wear rate [100]. Kaplan Meier gives a probability of $94 \%$ of keeping the prosthesis for 8 years [101]. Poor treatment results in hemiarthroplasty were observed regardless of them being cemented or not due to failure to restorate neck length and offset [102-105].

The rate of dislocation of THA was reported between in up to $15 \%$ of using standard approaches to the hip joint [106]. $R$ rate of revision was higher in patients treated for fractures than in those treated for other reasons with dislocation and periprosthetic fracture being the most frequent causes of revision $[38,107,108]$, as usual 10-year survivorship is around 99\% [109].

Initial costs of THA are higher compared to unipolar or bipolar hemiarthroplasty. However, overall costs, including those for revision surgery are lower the outcome of THA is better. In conclusion, THA is recommended as an evidence-based primary treatment for femoral neck fractures in the elderly. 


\section{Conclusions}

Total hip arthroplasty is the treatment of choice for femoral neck fractures in patients older than 60 years. Bipolar hemiarthroplasty were shown to be of limited value. Monopolar hemiarthroplasty should only be implanted in patients with limited life expectancy and/ or very low functional demands. Total hip arthroplasty ought to be performed by a qualified surgeon in a decent environment of a medium to large trauma or orthopaedic center. Using an anterior approach to the hip enables the patient to immediate full weight bearing.

\section{Acknowledgements}

The authors thank Juergen W. Schmitt, MD, Department of Surgery, Division of Trauma Surgery for providing radiographies of patients.

\section{Authors' contributions}

CO carried out the literature research and drafted the manuscript. MJS carried out the literature research and participated in drafting the manuscript. GAW and HPS participated in the design of the study and helped to draft the manuscript. CMLW conceived the study, participated in its design drafted the manuscript. All authors read and approved the final manuscript.

\section{Competing interests}

The authors declare that they have no competing interests.

Received: 11 July 2010 Accepted: 20 October 2010

Published: 20 October 2010

\section{References}

1. Miyamoto RG, Kaplan KM, Levine BR, Egol KA, Zuckerman JD: Surgical management of hip fractures: an evidence-based review of the literature. I: femoral neck fractures. J Am Acad Orthop Surg 2008, 16:596-607.

2. Simonen $\mathrm{O}$ : Incidence of femoral neck fractures: senile osteoporosis in Finland in the years 1970-1985. Calcif Tissue Int 1991, 49(Suppl):8-10.

3. Macaulay W, Pagnotto MR, lorio R, Mont MA, Saleh KJ: Displaced femoral neck fractures in the elderly: hemiarthroplasty versus total hip arthroplasty. J Am Acad Orthop Surg 2006, 14:287-293.

4. Zlowodzki M, Tornetta P, Haidukewych G, Hanson BP, Petrisor B, Swiontkowski MF, et al: Femoral neck fractures: evidence versus beliefs about predictors of outcome. Orthopedics 2009, 32[http://orthosupersite. com/view.asp?rlD=38062].

5. Dai Z, Li Y, Jiang D: Meta-Analysis Comparing Arthroplasty with Internal Fixation for Displaced Femoral Neck Fracture in the Elderly. J Surg Res 2009.

6. Benterud JG, Kok WL, Alho A: Primary and secondary Charnley-Hastings hemiarthroplasty in displaced femoral neck fractures and their sequelae. Ann Chir Gynaecol 1996, 85:72-76.

7. Bezwada HP, Shah AR, Harding SH, Baker J, Johanson NA, Mont MA: Cementless bipolar hemiarthroplasty for displaced femoral neck fractures in the elderly. J Arthroplasty 2004, 19(Suppl 2):73-77.

8. Bochner RM, Pellicci PM, Lyden JP: Bipolar hemiarthroplasty for fracture of the femoral neck. Clinical review with special emphasis on prosthetic motion. J Bone Joint Surg Am 1988, 70:1001-1010.

9. Casserly HB, Healy B: The Monk Hard-Top prosthesis for displaced intracapsular fractures of the femoral neck. Ir J Med Sci 1991, 160:5-7.

10. Chandran P, Azzabi M, Burton DJ, Andrews M, Bradley JG: Mid term results of Furlong LOL uncemented hip hemiarthroplasty for fractures of the femoral neck. Acta Orthop Belg 2006, 72:428-433.

11. Dixon S, Bannister G: Cemented bipolar hemiarthroplasty for displaced intracapsular fracture in the mobile active elderly patient. Injury 2004, 35:152-156.

12. Fang CH, Lee TS, Hsu KC: Clinical experience of hemiarthroplasty with Bateman bipolar endoprosthesis. Gaoxiong Yi Xue Ke Xue Za Zhi 1990, 6:268-275.
13. Giliberty RP: Hemiarthroplasty of the hip using a low-friction bipolar endoprosthesis. Clin Orthop Relat Res 1983, 175:86-92.

14. Goldhill VB, Lyden JP, Cornell CN, Bochner RM: Bipolar hemiarthroplasty for fracture of the femoral neck. J Orthop Trauma 1991, 5:318-324.

15. Lausten GS, Vedel P: The Monk hard-top endoprosthesis for intracapsular fractures of the femoral neck. Injury 1981, 13:233-238.

16. Lausten GS, Vedel P, Nielsen PM: Fractures of the femoral neck treated with a bipolar endoprosthesis. Clin Orthop Relat Res 1987, 218:63-67.

17. McConville OR, Bowman AJ Jr, Kilfoyle RM, McConville JF, Mayo RA: Bipolar hemiarthroplasty in degenerative arthritis of the hip. 100 consecutive cases. Clin Orthop Relat Res 1990, 251:67-74.

18. Miller D, Choksey A, Jones P, Perkins R: Medium to long term results of the Exeter bipolar hemiarthroplasty for femoral neck fractures in active, independent patients. 5-13 year follow-up. Hip Int 2008, 18:301-306.

19. Muller CA, Bayer J, Szarzynski E, Sudkamp NP: Implantation of bipolar prosthesis for treatment of medial femoral neck fractures in the elderlyclinical and radiographic outcome. Zentralbl Chir 2008, 133:590-596.

20. Overgaard S, Jensen $T$, Bonde G, Mossing NB: The uncemented bipolar hemiarthroplasty for displaced femoral neck fractures. 6-year follow-up of 171 cases. Acta Orthop Scand 1991, 62:115-120.

21. Moore AT: The self-locking metal hip prosthesis. J Bone Joint Surg Am 1957, 39:811-827.

22. Thompson FR: Vitallium intramedullary hip prosthesis, preliminary report. N Y State J Med 1952, 52:3011-3020.

23. Bateman JE: Single-assembly total hip prosthesis-preliminary report. Clin Orthop Relat Res 1990, 251:3-6, 1974.

24. Nottage WM, McMaster WC: Comparison of bipolar implants with fixedneck prostheses in femoral-neck fractures. Clin Orthop Relat Res 1990, 251:38-43.

25. Swiontkowski MF: Intracapsular fractures of the hip. J Bone Joint Surg Am 1994, 76:129-138.

26. Vazquez-Vela G, Vazquez-Vela E, Garcia DF: The Bateman bipolar prosthesis in osteoarthritis and rheumatoid arthritis. A review of 400 cases. Clin Orthop Relat Res 1990, 251:82-86.

27. D'Arcy J, Devas M: Treatment of fractures of the femoral neck by replacement with the Thompson prosthesis. J Bone Joint Surg Br 1976, 58:279-286.

28. Montgomery SP, Lawson LR: Primary Thompson prosthesis for acute femoral neck fractures. Clin Orthop Relat Res 1978, 137:62-68.

29. Tonino AJ: The Thompson prosthesis in the treatment of subcapital fractures of the neck of the femur. Int Orthop 1982, 6:225-231.

30. Bauer R, Kerschbaumer F, Poisel S, Oberthaler W: The transgluteal approach to the hip joint. Arch Orthop Trauma Surg 1979, 95:47-49.

31. Chen DW, Hu CC, Chang YH, Yang WE, Lee MS: Comparison of clinical outcome in primary total hip arthroplasty by conventional anterolateral transgluteal or 2-incision approach. J Arthroplasty 2009, 24:528-532.

32. Heimkes B, Posel P, Bolkart M: The transgluteal approaches to the hip. Arch Orthop Trauma Surg 1992, 111:220-223.

33. Miozzari HH, Dora C, Clark JM, Notzli HP: Late Repair of Abductor Avulsion After the Transgluteal Approach for Hip Arthroplasty. J Arthroplasty 2010, 25:450-457.

34. Nazarian S, Tisserand P, Brunet C, Muller ME: Anatomic basis of the transgluteal approach to the hip. Surg Radiol Anat 1987, 9:27-35.

35. Rogers M, Blom AW, Barnett A, Karantana A, Bannister GC: Revision for recurrent dislocation of total hip replacement. Hip Int 2009, 19:109-113.

36. Parvizi J, Pour AE, Peak EL, Sharkey PF, Hozack WJ, Rothman RH: One-stage bilateral total hip arthroplasty compared with unilateral total hip arthroplasty: a prospective study. J Arthroplasty 2006, 21(Suppl 2):26-31.

37. Tidermark J, Ponzer S, Svensson O, Soderqvist A, Tornkvist H: Internal fixation compared with total hip replacement for displaced femoral neck fractures in the elderly. A randomised, controlled trial. J Bone Joint Surg Br 2003, 85:380-308.

38. Phillips TW: The Bateman bipolar femoral head replacement. A fluoroscopic study of movement over a four-year period. I Bone Joint Surg Br 1987, 69:761-764

39. Bhattacharyya T, Koval KJ: Unipolar versus bipolar hemiarthroplasty for femoral neck fractures: is there a difference? J Orthop Trauma 2009, 23:426-427.

40. Cornell CN, Levine D, O'Doherty J, Lyden J: Unipolar versus bipolar hemiarthroplasty for the treatment of femoral neck fractures in the elderly. Clin Orthop Relat Res 1998, 348:67-71. 
41. Davison JN, Calder SJ, Anderson GH, Ward G, Jagger C, Harper WM, et al: Treatment for displaced intracapsular fracture of the proximal femur. A prospective, randomised trial in patients aged 65 to 79 years. J Bone Joint Surg Br 2001, 83:206-212.

42. Ong BC, Maurer SG, Aharonoff GB, Zuckerman JD, Koval KJ: Unipolar versus bipolar hemiarthroplasty: functional outcome after femoral neck fracture at a minimum of thirty-six months of follow-up. J Orthop Trauma 2002, 16:317-322.

43. Raia FJ, Chapman CB, Herrera MF, Schweppe MW, Michelsen CB, Rosenwasser MP: Unipolar or bipolar hemiarthroplasty for femoral neck fractures in the elderly? Clin Orthop Relat Res 2003, 414:259-265.

44. Leighton RK, Schmidt AH, Collier P, Trask K: Advances in the treatment of intracapsular hip fractures in the elderly. Injury 2007, 38(Suppl 3):24-34.

45. Schliemann B, Seybold D, Gessmann J, Fehmer T, Schildhauer TA, Muhr G: Bipolar Hemiarthroplasty in Femoral Neck Fractures - Impact of Duration of Surgery, Time of Day and the Surgeon's Experience on the Complication Rate. Z Orthop Unfall 2009, 147:689-693.

46. Dorr LD, Glousman R, Hoy AL, Vanis R, Chandler R: Treatment of femoral neck fractures with total hip replacement versus cemented and noncemented hemiarthroplasty. J Arthroplasty 1986, 1:21-28.

47. Keating JF, Grant A, Masson M, Scott NW, Forbes JF: Displaced intracapsular hip fractures in fit, older people: a randomised comparison of reduction and fixation, bipolar hemiarthroplasty and total hip arthroplasty. Health Technol Assess 2005, 9:1-65.

48. Keating JF, Grant A, Masson M, Scott NW, Forbes JF: Randomized comparison of reduction and fixation, bipolar hemiarthroplasty, and total hip arthroplasty. Treatment of displaced intracapsular hip fractures in healthy older patients. J Bone Joint Surg Am 2006, 88:249-260.

49. Lecerf G, Fessy MH, Philippot R, Massin P, Giraud F, Flecher X, et al: Femoral offset: anatomical concept, definition, assessment, implications for preoperative templating and hip arthroplasty. Orthop Traumatol Surg Res 2009, 95:210-219.

50. Abraham WD, Dimon JH III: Leg length discrepancy in total hip arthroplasty. Orthop Clin North Am 1992, 23:201-219.

51. Barlas KJ, Ajmi QS, Bagga TK, Howell FR, Roberts JA, Eltayeb M: Association of intra-operative metaphyseal fractures with prosthesis size during hemiarthroplasty of the hip. J Orthop Surg (Hong Kong) 2008, 16:30-34.

52. Barnes $\mathrm{CL}$, Berry DJ, Sledge CB: Dislocation after bipolar hemiarthroplasty of the hip. J Arthroplasty 1995, 10:667-669.

53. Figved W, Norum OJ, Frihagen F, Madsen JE, Nordsletten L: Interprosthetic dislocations of the Charnley/Hastings hemiarthroplasty-report of 11 cases in 350 consecutive patients. Injury 2006, 37:157-161.

54. Figved W, Dybvik E, Frihagen F, Furnes O, Madsen JE, Havelin LI, et al: Conversion from failed hemiarthroplasty to total hip arthroplasty: a Norwegian Arthroplasty Register analysis of 595 hips with previous femoral neck fractures. Acta Orthop 2007, 78:711-718.

55. Blomfeldt R, Tornkvist H, Ponzer S, Soderqvist A, Tidermark J: Comparison of internal fixation with total hip replacement for displaced femoral neck fractures. Randomized, controlled trial performed at four years. J Bone Joint Surg Am 2005, 87:1680-688.

56. Calton TF, Fehring TK, Griffin WL, McCoy TH: Failure of the polyethylene after bipolar hemiarthroplasty of the hip. A report of five cases. J Bone Joint Surg Am 1998, 80:420-423.

57. Barmada R, Siegel IM: Postoperative separation of the femoral and acetabular components of a single-assembly total hip (Bateman) replacement. J Bone Joint Surg Am 1979, 61:777-778.

58. Barmada R, Mess D: Bateman hemiarthroplasty component disassembly. A report of three cases of high-density polyethylene failure. Clin Orthop Relat Res 1987, 224:147-149.

59. Georgiou G, Siapkara A, Dimitrakopoulou A, Provelengios S, Dounis E: Dissociation of bipolar hemiarthroplasty of the hip after dislocation. A report of five different cases and review of literature. Injury 2006, 37:162-168.

60. Hasegawa M, Sudo A, Uchida A: Disassembly of bipolar cup with selfcentering system: a report of seven cases. Clin Orthop Relat Res 2004, 425:163-167.

61. Mollers M, Stedtfeld HW, Paechtner S, Wald A: Hemi-arthroplasty of the hip joint: concentric or positive eccentric (self-centering) dual head prosthesis? A retrospective comparison. Unfallchirurg 1992, 95:224-229.

62. Chen TH, Huang CK, Chen WM, Chiang CC, Lo WH: Heterotopic ossification after cemented or uncemented bateman bipolar hemiarthroplasty. Zhonghua Yi Xue Za Zhi (Taipei) 1998, 61:520-523.
63. Kenzora JE, Magaziner J, Hudson J, Hebel JR, Young Y, Hawkes W, et al: Outcome after hemiarthroplasty for femoral neck fractures in the elderly. Clin Orthop Relat Res 1998, 348:51-58.

64. Ichihashi K, Imura S, Oomori H, Gesso H: Stress analysis on the acetabular side of bipolar hemiarthroplasty by the two-dimensional finite element method incorporating the boundary friction layer. Nippon Seikeigeka Gakkai Zasshi 1994, 68:939-952.

65. Devas M, Hinves B: Prevention of acetabular erosion after hemiarthroplasty for fractured neck of femur. J Bone Joint Surg Br 1983, 65:548-551.

66. Langan P: The Giliberty bipolar prosthesis: a clinical and radiographical review. Clin Orthop Relat Res 1979, 141:169-175.

67. Long JW, Knight W: Bateman UPF prosthesis in fractures of the femoral neck. Clin Orthop Relat Res 1980, 152:198-201.

68. Coleman SH, Bansal M, Cornell CN, Sculco TP: Failure of bipolar hemiarthroplasty: a retrospective review of 31 consecutive bipolar prostheses converted to total hip arthroplasty. Am J Orthop 2001, 30:313-319.

69. Moon KH, Kang JS, Lee TJ, Lee SH, Choi SW, Won MH: Degeneration of acetabular articular cartilage to bipolar hemiarthroplasty. Yonsei Med J 2008, 49:719-724.

70. Heetveld MJ, Rogmark C, Frihagen F, Keating J: Internal fixation versus arthroplasty for displaced femoral neck fractures: what is the evidence? J Orthop Trauma 2009, 23:395-402.

71. Broos PL, Stappaerts KH, Luiten EJ, Gruwez JA: Home-going: prognostic factors concerning the major goal in treatment of elderly hip fracturepatients. Int Surg 1988, 73:148-150.

72. Broos PL: Prosthetic replacement in the management of unstable femoral neck fractures in the elderly. Analysis of the mechanical complications noted in 778 fractures. Acta Chir Belg 1999, 99:190-194.

73. Simon P, Gouin F, Veillard D, Laffargue P, Ehlinger M, Bel JC, et al: Femoral neck fractures in patients over 50 years old. Rev Chir Orthop Reparatrice Appar Mot 2008, 94(Suppl 6):108-132.

74. Lei G, Zeng K, Li K: Short-term follow-up of ribbed anatomic cementless total hip arthroplasty. Zhongguo Xiu Fu Chong Jian Wai Ke Za Zhi 2007, 21:244-6.

75. Mainard D, Guillemin F, Cuny C, Mejat-Adler E, Galois L, Delagoutte J: Quality of life assessment one year after total hip or knee arthroplasty. Rev Chir Orthop Reparatrice Appar Mot 2000, 86:464-473.

76. Macaulay W, Nellans KW, Garvin KL, lorio R, Healy WL, Rosenwasser MP: Prospective randomized clinical trial comparing hemiarthroplasty to total hip arthroplasty in the treatment of displaced femoral neck fractures: winner of the Dorr Award. J Arthroplasty 2008, 23(Suppl 1):2-8.

77. Eiskjaer S, Ostgard SE: Risk factors influencing mortality after bipolar hemiarthroplasty in the treatment of fracture of the femoral neck. Clin Orthop Relat Res 1991, 270:295-300.

78. Petersen MB, Jorgensen HL, Hansen K, Duus BR: Factors affecting postoperative mortality of patients with displaced femoral neck fracture. Injury 2006, 37:705-711.

79. Smektala R, Endres HG, Dasch B, Maier C, Trampisch HJ, Bonnaire F, Pientka $L$ : The effect of time-to-surgery on outcome in elderly patients with proximal femoral fractures. BMC Musculoskelet Disord 2008, 9:171.

80. Vertelis A, Robertsson O, Tarasevicius S, Wingstrand H: Delayed hospitalization increases mortality in displaced femoral neck fracture patients. Acta Orthop 2009, 80:683-686.

81. Hommel A, Ulander $\mathrm{K}$, Bjorkelund KB, Norrman PO, Wingstrand $\mathrm{H}$, Thorngren KG: Influence of optimised treatment of people with hip fracture on time to operation, length of hospital stay, reoperations and mortality within 1 year. Injury 2008, 39:1164-1174.

82. Sebestyen A, Boncz I, Toth F, Pentek M, Nyarady J, Sandor J: Correlation between risk factors and mortality in elderly patients with femoral neck fracture with 5-year follow-up. Orv Hetil 2008, 149:493-503.

83. Muir SW, Yohannes AM: The impact of cognitive impairment on rehabilitation outcomes in elderly patients admitted with a femoral neck fracture: a systematic review. J Geriatr Phys Ther 2009, 32:24-32.

84. Kuzyk PR, Guy P, Kreder HJ, Zdero R, McKee MD, Schemitsch EH: Minimally invasive hip fracture surgery: are outcomes better? J Orthop Trauma 2009, 23:447-453.

85. Matta JM, Shahrdar C, Ferguson T: Single-incision anterior approach for total hip arthroplasty on an orthopaedic table. Clin Orthop Relat Res 2005, 441:115-124. 
86. Matta JM, Ferguson TA: The anterior approach for hip replacement. Orthopedics 2005, 28:927-928.

87. Sierra RJ, Raposo JM, Trousdale RT, Cabanela ME: Dislocation of primary THA done through a posterolateral approach in the elderly. Clin Orthop Relat Res 2005, 441:262-267.

88. Konan S, Rhee SJ, Haddad FS: Total hip arthroplasty for displaced fracture of the femoral neck using size $32 \mathrm{~mm}$ femoral head and soft tissue repair after a posterior approach. Hip Int 2009, 19:30-35.

89. Blomfeldt R, Tornkvist H, Eriksson K, Soderqvist A, Ponzer S, Tidermark J: A randomised controlled trial comparing bipolar hemiarthroplasty with total hip replacement for displaced intracapsular fractures of the femoral neck in elderly patients. J Bone Joint Surg Br 2007, 89:160-165.

90. Blomfeldt R, Tornkvist H, Ponzer S, Soderqvist A, Tidermark J: Displaced femoral neck fracture: comparison of primary total hip replacement with secondary replacement after failed internal fixation: a 2-year follow-up of 84 patients. Acta Orthop 2006, 77:638-643.

91. Iorio R, Healy WL, Lemos DW, Appleby D, Lucchesi CA, Saleh KJ: Displaced femoral neck fractures in the elderly: outcomes and cost effectiveness. Clin Orthop Relat Res 2001, 383:229-42.

92. Schleicher I, Kordelle J, Jurgensen I, Haas H, Melzer C: Femoral neck fractures in the elderly - bipolar hemiarthroplasty in total hip replacement. Unfallchirurg 2003, 106:467-471.

93. Diwanji SR, Kim SK, Seon JK, Park SJ, Yoon TR: Clinical results of conversion total hip arthroplasty after failed bipolar hemiarthroplasty. J Arthroplasty 2008, 23:1009-1015.

94. Angelini M, McKee MD, Waddell JP, Haidukewych G, Schemitsch EH: Salvage of failed hip fracture fixation. J Orthop Trauma 2009, 23:471-478,

95. Aleem IS, Karanicolas PJ, Bhandari M: Arthroplasty versus internal fixation of femoral neck fractures: a clinical decision analysis. Ortop Traumatol Rehabil 2009, 11:233-241.

96. Browne JA, Pietrobon R, Olson SA: Hip fracture outcomes: does surgeon or hospital volume really matter? J Trauma 2009, 66:809-814.

97. Lemaire R, Rodriguez A: Radiological study of the migration of prosthetic implants following hip arthroplasty. Acta Orthop Belg 1996, 62(Suppl 1):124-131.

98. Langlais F, Lambotte JC, Thomazeau H, Dreano T: Wear and loosening of prostheses. Chirurgie 1997, 122:232-236.

99. Hernigou P, Bahrami T: Total hip prostheses, friction lever and wear. Chirurgie 1997, 122:229-231.

100. Kerboull L, Hamadouche M, Courpied JP, Kerboull M: Long-term results of Charnley-Kerboull hip arthroplasty in patients younger than 50 years. Clin Orthop Relat Res 2004, 418:112-118.

101. Sedel L, Christel P, Kerboull L, Witvoet J: Total hip prosthesis in patients less than 50 years of age. Value of ceramic materials. Rev Rhum Mal Osteoartic 1990, 57:605-611.

102. Dangles CJ, Altstetter CJ: Failure of the Modular Neck in a Total Hip Arthroplasty. J Arthroplasty 2009.

103. Heck DA, Partridge CM, Reuben JD, Lanzer WL, Lewis CG, Keating EM: Prosthetic component failures in hip arthroplasty surgery. J Arthroplasty 1995, 10:575-580.

104. Lam LO, Stoffel K, Kop A, Swarts E: Catastrophic failure of 4 cobalt-alloy Omnifit hip arthroplasty femoral components. Acta Orthop 2008, 79:18-21.

105. Phillips TW, Johnston G, Wood P: Selection of an animal model for resurfacing hip arthroplasty. J Arthroplasty 1987, 2:111-117.

106. Cartlidge IJ: Primary total hip replacement for displaced subcapital femoral fractures. Injury 1981, 13:249-253.

107. Leonardsson O, Sernbo I, Carlsson A, Akesson K, Rogmark C: Long-term follow-up of replacement compared with internal fixation for displaced femoral neck fractures: results at ten years in a randomised study of 450 patients. J Bone Joint Surg Br 2010, 92:406-412.

108. Eyssel M, Schwenk W, Badke A, Krebs S, Stock W: Total endoprosthesis or dual head prosthesis in endoprosthetic management of femoral neck fractures? Unfallchirurg 1994, 97:347-352.

109. Delaunay C, Kapandji Al: 10-year survival of Zweymuller total prostheses in primary uncemented arthroplasty of the hip. Rev Chir Orthop Reparatrice Appar Mot 1998, 84:421-432.

doi:10.1186/1754-9493-4-16

Cite this article as: Ossendorf et al:: Treatment of femoral neck fractures in elderly patients over 60 years of age - which is the ideal modality of primary joint replacement? Patient Safety in Surgery 2010 4:16.

\section{Submit your next manuscript to BioMed Central and take full advantage of:}

- Convenient online submission

- Thorough peer review

- No space constraints or color figure charges

- Immediate publication on acceptance

- Inclusion in PubMed, CAS, Scopus and Google Scholar

- Research which is freely available for redistribution 